\title{
What We Shall Miss About Gerry Larson
}

\section{Pravrajika Vrajaprana ${ }^{1}$}

Published online: 1 November 2019

(C) Springer Nature Switzerland AG 2019

If you are reading this, you already know that Gerry was a brilliant scholar with a healthy string of publications under his belt, including his $1000+$ page magnum opus Classical Yoga Philosophy and the Legacy of Sämkhya. Were you a student of Gerry's, you know that he was a superb, if exacting, teacher. Students would occasionally be brought to tears, which surprised him, but his standards remained high. What many of those students did not know was how much Gerry cared for them, bringing him to occasional tears. His graduate students in particular were like family members, and he both rejoiced with and fretted over them.

Many people were intimidated by Gerry - his brilliance was widely acknowledged, he never met an argument he did not love, and he habitually charged in where angels feared to tread.

Sometimes it was helpful. Once Gerry attended a Santa Barbara Symphony concert and I was in the choir onstage. He later said, "I saw you onstage. Why wasn't your name in the program?" I told him that I used my legal English name because I did not think my fellow singers would be able to deal with Pra-vra-ji-ka Vra-ja-pra-na. He responded sharply: "Are you embarrassed about your name?"

"Of course not!" I shot back. "I am deeply proud of my name and my tradition." "Then why don't you give the other musicians a chance to learn something?" he replied softly. "You may be surprised." He was right.

This says so much about Gerry: his belief in the power of education to enlighten, his belief in the importance of open communication, and his understanding that forthrightness is essential to our intellectual and spiritual integrity.

While we vigorously and endlessly argued about my Vedānta philosophy versus his cherished Sāmphya — he called me "Vacuous One (in the night in which all cows are black)" and I called him Svāmi Kleśānanda- one thing we stood shoulder to shoulder on was the importance of the academy listening to the views of the believing community and having open and respectful communication with them. The believing communities have not necessarily left their intellects at the temple door just as those in the academy aren't necessarily condescending or hostile. We can and should learn from

Pravrajika Vrajaprana vrajaprana@mac.com

1 Vedanta Society of Southern California, Santa Barbara, USA 
each other and benefit from one another's approach. As Gerry wrote in an article for the Journal of the American Academy of Religion:

"It is important for all of us in the modern academy to be in frank and open conversation with the communities we study . . . I am, therefore, personally persuaded that the relation of symmetrical reciprocity ... is the only way to go if we wish our studies to be taken seriously and if we wish our studies to be properly nuanced and persuasive."

We will miss Gerry's brilliance, his insights, his joy and humor, his gleeful charging into battles, his uncompromising integrity, and his loving heart. I sorely miss our arguments and volleys of Sanskrit insults. When one of our nuns died, he sent a touching tribute. As I wrote him, "Despite your appalling ajñanna, you really have the sweetest soul." That I shall miss most of all.

My choir struggles heroically with my Sanskrit name, with respect and curiosity. I have to thank Gerry for that, who taught me an important lesson, not gleaned from Sāmkhya but from his splendid character.

Publisher's Note Springer Nature remains neutral with regard to jurisdiction-al claims in published maps and institutional affiliations.

\footnotetext{
${ }^{1}$ Gerald James Larson, "Polymorphic Sexuality, Homoeroticism, and the Study of Religion Revisited: A Rejoinder," JAAR 65 (1997), no 3: 664. 